To Maega | Jurnal Pengabdian Masyarakat

Februari 2021, Vol.4, No.1, hal, 71-80

$\operatorname{ISSN}(P): 2622-6332 ; \operatorname{ISSN}(E): 2622-6340$

TOMAEGA http://www.ojs.unanda.ac.id/index.php/tomaega

\title{
Peningkatan Ekonomi Masyarakat Melalui Pembuatan Pola Ruang
}

Muhammad Suayib ${ }^{1}$, Wahyu ${ }^{1}$, Marwah Yusuf ${ }^{1, *}$, Anwar $^{1}$, Samsul Alam ${ }^{1}$

${ }^{1}$ Program Studi akuntansi, Ekonomi, Stiem Bongaya Makassar

Correspondent Author: marwahyusuf@yahoo.co ${ }^{3}$

Article History:

Received: 20-11-2020; Received in Revised: 16-12-2020; Accepted: 28-12-2020 DOI: http://dx.doi.org/10.35914/tomaega.v4i1.516

\section{Abstrak}

Dalam pembuatan pola ruang ini, mempunyai tujuan utama yaitu memanfaatkan sumber daya alam (SDA) masyarakat. Karena sumber daya alam yang melimpah, bukan berarti tingkat pendapatan dan kesejahteraan masyarakat akan meningkat. Hal itu terjadi jika masyarakat kurang memanfaatkan sumber daya alam yang ada.Oleh karena itu, semua sektor sumber daya alam harus dimanfaatkan sebaik mungkin.Dengan melakukan eksperimen atau uji coba dalam pembuatan pola ruang merupakan langkah yang tepat untuk memanfaatkan sumber daya alam tersebut.

Kata kunci : pemanfaatan sumber daya alam, pola ruang.

\section{Abstract}

In making this spatial pattern, the main objective is to utilize the natural resources (SDA) of the community. Because natural resources are abundant, it does not mean that the level of income and welfare of the community will also increase. This happens when the community does not make use of existing natural resources. Therefore, all sectors of natural resources must be put to the best possible use. By conducting experiments or trials in making spatial patterns is the right step to take advantage of these natural resources.

Keywords : utilization of natural resources, spatial patterns.

\section{Pendahuluan}

Meningkatkan perekonomian di desa sangatlah penting, hal ini dikarenakan mayoritas penduduk di Indonesia merupakan masyarakat desa. Ekonomi masyarakat desa ditopang oleh beberapa sektor pendapatan diantaranya melalui kegiatan permberdayaan masyarakat yang harus ditingkatkan agar ekonomi masyarakat desa bisa maju dan berkembang (Danial dkk, 2019). Sadono Sukirno dalam Marlinah (2018) mendefenisikan pembangunan ekonomi sebagai suatu proses yang menyebabkan pendapatan perkapita penduduk suatu masyarakat meningkat dalam jangka panjang.

Pembangunan ekonomi merupaka suatu perubahan dalam lapangan industri dan perdagangan yang berkaitan dengan pedapatan perkapita dan pendapatan nasional dimana proses tersebut terjadi secara spontan dan tidak teputus-putus (Suryana, 2000). Selain itu pembangunan ekonomi merupakan hal yang sangat 
[72] Muhammad Suayib, dkk / To Maega : Jurnal Pengabdian Masyarakat, Vol. 4; No.1.; Februari, 2021

penting bagi suatu negara maupun suatu wilayah karna ini akan mengacu pada pendapatan negara maupun wilayah sebab semakin besar pendapatan negara atau pendapatan wilayah maka dapat dipastikan semakin tinggi pertumbuhan ekonomi yang berdampaka pada peningkatan kesejahteraan masyarakat (Didiharyono dkk, 2018).

Beberapa sektor perokonomian yang mengalami kendala sangat mempengaruhi penurunan pendapatan ekonomi. Selain sektor perekonomian tersebut yang harus ditingkatkan, adapun faktor yang mempengaruhi kondisi ekonomi masyarakat di desa. Maka dari itu peningkatan sektor perekonomian terkait bidang perencanaan pemberdayaan masyarakat desa yaitu meningkatkan sektor perekonomian juga meningkatkan potensi yang mempengaruhi kondisi ekonomi masyarakat (Sapareng \& Rosnina, 2019). Faktor yang mempengaruhi kondisi ekonomi masyarakat desa diantaranya (1) Sumber daya alam. Desa yang kaya akan sumber daya alam maka perekonomiannya akan lebih maju. Contohnya, kondisi tanah yang subur, jika suatu desa mempunyai tanah yang subur maka banyak potensi yang bisa didapat dari sumber daya alam tersebut. (2) Kebijakan dari pemerintah, masyarakat desa mengharapkan sebuah kebijakan yang mampu meningkatkan kesejahteraan masyarakat desa.

Kebijakan yang dianggap menguntungkan seperti berbagai subsidi untuk menunjang sektor peternakan. (3) Jumlah penduduk desa juga mempengaruhi kesejahteraan masyarakat. Di desa pada umumnya mayoritas memiliki banyak anak dibandingkan masyarakat yang tinggal di kota. Jumlah anggota keluarga yang banyak ini secara tidak langsung mempengaruhi ekonomi di desa. (4), Tingkat pendidikan masyarakat Desa. Untuk urusan kualitas pendidikan, masyarakat desa masih jauh tertinggal dengan masyarakat perkotaan. Sehingga diperlukan peningkatan budaya literasi masyarakat desa yang dapat mempengaruhi kondisi pendidikan dan peningkatan ekonomi pada masyarakat desa (Didiharyono \& Qur'ani, 2019).

Kegiatan pengembangan masyarakat merupakan kegiatan yang ditujukan untuk mengembangkan suatu kelompok masyarakat tertentu di suatu daerah. Dalam bahasa populer sekarang ini sering juga dikenal dengan istilah kegiatan pemberdayaan (empowerment) masyarakat. Kegiatan-kegiatan seperti ini berkembang marak di indonesia belakangan ini karena ternyata kebijakan umum ekonomi yang ada tidak mampu memberikan manfaat bagi kelompok-kelompok masyarakat tertentu (Intisari \& Rosnina, 2019). Tujuan kegiatan ini adalah untuk menciptakan manfaat sosial, misalnya melalui penciptaan proyek-proyek padat karya untuk memenuhi keuntungan dari usahanya. Pemanfaatan sosial serta penciptaan proyek padat karya dapat dilaksanakan dengan menggunakan beberapa 
[73] Muhammad Suayib, dkk / To Maega : Jurnal Pengabdian Masyarakat, Vol. 4; No.1.; Februari, 2021

strategi pertumbuhan pembangunan yang dapat menunjang terlaksananya suatu perencanaan (Indardi, 2018).

Strategi pertumbuhan dan pembangunan ekonomi daerah sangat mutlak diperlukan serta diterapkan dalam rangka mempercepat pertumbuhan dan pembangunan ekonomi daerah yang bersangkutan.Untuk itu peran pemerintah sangat penting untuk mendorong bahkan meningkatkan kapasitas pembangunan ekonomi suatu daerah dengan berdasarkan pada kondisi serta potensi yang dimiliki oleh masing-masing daerah (Siwu, 2019).

Pola ruang merupakan pemanfaatan lahan yang diterapkan oleh pemerintah desa Sunggumanai Kecematan Pattalassang Kabupaten Gowa. Hal ini dapat menjadi landasan pengembangan kekuatan ekonomi khususnya daerah pemanfaatan pola ruang. Sumber daya dalam pola ruang bisa menjadi basis usaha perekonomian dan juga akan menopang semakin bertambahnya kebutuhan dari segala aspek. Pola ruang merupakan hasil ide dari Bpk Abd Rivai, kemudian dikembangkan lagi oleh para mahasiswa (i) yang melakukan pengabdian. Pola ruang awalnya merupakan lahan kosong yang hanya dimanfaatkan untuk berkebun, kini mengalami perubahan fungsi akibat pengaruh usaha ekonomi sehingga diubah menjadi 3 aspek kegiatan yakni : perkebunan, peternakan dan budidaya perikanan sehingga lebih produktif serta memanfaatkan lahan kecil menjadi sumber pendapatan yang lebih berdayaguna.

Pola ruang adalah distribusi peruntukan ruang dalam suatu wilayah yang meliputi peruntukan ruang untuk fungsi lindung dan peruntukan ruang untuk fungsi budidayanya. Didalam pola ruang terdapat tiga sub sistem yaitu budidaya pertanian, budidaya perternakan, dan budidaya perikanan. Tujuan dari pola ruang tersebut adalah untuk meningkatakan sumber pendapatan ekonomi suatu wilaya daerah atau desa. Dalam menetapkan dan membuat pola ruang hal utama yang perlu diperhatikan adalah SDAnya.Sumber daya alam menurut undang-undang no.4 tahun 1982 pasal (5) menyebutkan bahwa sumber daya alam adalah unsur lingkungan hidup yang terdiri atas sumber daya manusia, sumber daya hayati, sumber daya non hayati dan sumber daya buatan.Sumber daya hayati adalah sumber daya alam yang berasal dari makhluk hidup.Yang termasuk sumber daya alam hayati yakni tumbuhan, hewan, mikroba.Sumber daya alam non hayati adalah sumber daya alam yang bukan berasal dari makhluk hidup.Seperti emas, perak, nikel.

Pada umumnya, sumber daya alam berdasarkan sifatnya dapat digolongkan menjadi SDA yang dapat diperbaharui dan SDA tak dapat diperbaharui.SDA yang dapat diperbaharui adalah kekayaan alam yang dapat terus ada selama penggunaannya tidak dieksploitasi berlebihan.Tumbuhan, hewan, mikroorganisme, sinar matahari, angin, dan air adalah beberapa contoh SDA terbaharukan. 
[74] Muhammad Suayib, dkk / To Maega : Jurnal Pengabdian Masyarakat, Vol. 4; No.1.; Februari, 2021

Walaupun, jumlahnya sangat berlimpah di alam, penggunannya harus tetap dibatasi dan dijaga untuk dapat terus berkelanjutan. SDA tak dapat diperbaharui adalah SDA yang jumlahnya terbatas karena penggunaanya lebih cepat daripada proses pembentukannya dan apabila digunakan secara terus-menerus akan habis. Minyak bumi, emas, besi, dan berbagai bahan tambang lainnya pada umumnya memerlukan waktu dan proses yang sangat panjang untuk kembali terbentuk sehingga jumlahnya sangat terbatas., minyak bumi dan gas alam pada umumnya berasal dari sisa-sisa hewan dan tumbuhan yang hidup jutaan tahun lalu, terutama dibentuk dan berasal dari lingkungan perairan. Perubahan tekanan dan suhu panas selama jutaaan tahun ini kemudian mengubah materi dan senyawa organik tersebut menjadi berbagai jenis bahan tambang tersebut.

SDA dalam bahasa Inggris dikenal sebagai natural resources. Manfaat sumber daya alam penting untuk menjaga kelangsungan hidup manusia, sebagai penghasil bahan bakar dan energi, sebagai pembangkit listrik, memenuhi kebutuhan makanan manusia, menjaga keseimbangan alam dan lain sebagainya. SDA adalah unsurunsur lingkungan alam, baik fisik maupun hayati yang diperlukan manusia dalam memenuhi kebutuhannya guna meningkatkan kesejahteraan hidup (Suryana, 200). SDA adalah hasil penilaian manusia terhadap unsur-unsur lingkungan hidup yang diperlukannya, dimana terdapat 3 definisi sumber daya alam yakni persediaan total (total stock), sumber daya (resources) dan cadangan (reserve). Sumber daya alam sebagai keadaan lingkungan dan bahan-bahan mentah yang digunakan manusia untuk memenuhi kebutuhan dan memperbaiki kesejahteraannya (Soerianegara, 1997).

Kebanyakan pedesaan, terutama yang ada di wilayah negara-negara berkembang, mayoritas penduduknya hidup dari sektor pertanian. Karena mayoritas penduduk bergantung pada sektor pertanian, ini membuat pembangunan yang dilakukkan seringkali mengarah pada sektor pertanian. Padahal, pembangunan pertanian tidaklah sama dengan pembangunan pedesaan. Pembangunan pedesaan memiliki cakupan yang lebih luas dari sekedar pembangunan pertanian.Adapun pembangunan pedesaan ini harus disesuaikan dengan kondisi masing -masing wilayah. Kondisi ini juga menjadi penyebab terjadinya aliran tenaga kerja dari desa ke kota yang berlangsung secara masif. Masyarakat desa memang sering dirundung masalah kemiskinan dan keterbelakangan. Ini sebabnya, diperlukan adanya pembangunan ekonomi pedesaan melalui pemberdayaan masyarakat agar bisa mengatasi berbagai permasalahan yang terjadi di desa (Arico \& Jayanthi, 2018).

Ekonomi masyarakat desa ditopang oleh beberapa sektor pendapatan. Semua sektor inilah yang harus ditingkatkan agar ekonomi masyarakat desa bisa maju dan berkembang. Kegiatan masyarakat desa yaitu bercirikan homogen yang artinya 
[75] Muhammad Suayib, dkk / To Maega : Jurnal Pengabdian Masyarakat, Vol. 4; No.1.; Februari, 2021

suatu hal tersebut adalah sama, baik itu sifatnya, tingkah lakunya dan karakteristiknya. Pada umumnya sektor perokonomian di desa yaitu pertanian, peternakan, industri kreatif dan perikanan. Jika beberapa sektor perokonomian tersebut mengalami kendala maka akan membuat penurunan pendapatan ekonomi. Selain sektor perekonomian tersebut yang harus ditingkatkan.

Maka dari itu peningkatan sektor perekonomian terkait meningkatkan sektor perekonomian juga meningkatkan potensi yang mempengaruhi kondisi ekonomi masyarakat. Faktor yang mempengaruhi kondisi ekonomi masyarakat desa seperti Sumber daya alam dikarenakan desa yang kaya akan sumber daya alam maka perekonomiannya akan lebih maju (Andini, 2015). Contohnya berupa kondisi tanah yang subur, jika suatu desa mempunyai tanah yang subur maka banyak potensi yang bisa didapat dari sumber daya alam tersebut.

\section{Metode}

Tempat pelaksanaan pembuatan pola ruang yaitu berada di Dusun Japing Desa Sunggumanai Kecematan Pattallassang Kabupaten Gowa. Berlangsung selama 21 hari dari tanggal 6 - 27 Agustus 2020. Metode yang digunakan dalam kegiatan ini meliputi metode sebagai berikut:

- Analisis situasi.

Metode ini bertujuam untuk memahami jenis permasalahan yang ingin ditangani dalam program peningkatan ekonomi di bidang pertanian, peternakanm dan perikanan di daerah pedesaan.

- Persiapan.

Hal-hal yang dipersiapkan meliputi alat dan bahan yang digunakan dalam pembuatan pola ruang.

- Pelaksanaan.

Pelaksanaan didahului dengan mengumpulkan semua alat dan bahan, kemudian dilakukan pembuatan secara bertahap dari awal sampai selesai.

\section{Hasil dan Pembahasan}

Pola ruang adalah distribusi peruntukan ruang dalam suatu wilayah yang meliputi peruntukan ruang untuk fungsi lindung dan peruntukan ruang untuk fungsi budi daya. Penataan ruang adalah suatu sistem proses perencanaan tata ruang, pemanfaatan ruang, dan pengendalian pemanfaatan ruang. Ruang adalah wadah yang meliputi ruang darat, ruang laut, dan ruang udara, termasuk ruang di dalam bumi sebagai satu kesatuan wilayah, tempat manusia dan makhluk lain hidup, melakukan kegiatan, dan memelihara kelangsungan hidupnya.Tata ruang adalah wujud struktur ruang dan pola ruang. Struktur ruang adalah susunan pusat-pusat 
[76] Muhammad Suayib, dkk / To Maega : Jurnal Pengabdian Masyarakat, Vol. 4; No.1.; Februari, 2021

permukiman dan sistem jaringan prasarana dan sarana yang berfungsi sebagai pendukung kegiatan sosial ekonomi masyarakat yang secara hirarkis memiliki hubungan fungsional. Adapun proses pembuatan dari pembuatan pola ruang, yaitu:

1. Pengambilan dan pemasangan bambu dalam pembuatan pola ruang.

Kegiatan ini dilakukan secara bersama-sama dengan model gotong royong yang dilakukan oleh masyarakat dan beberapa mahasiswa yang terlibat.

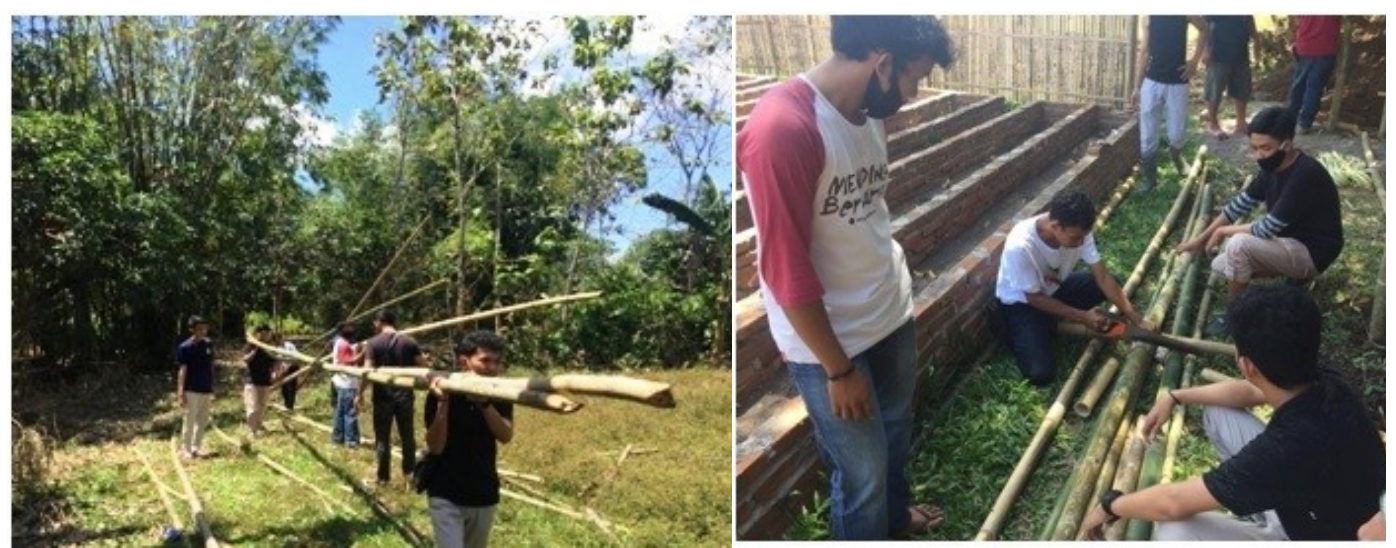

Gambar 1. Bahan Bambu Dalam Pembuatan Pola Ruang

Gambar 2. Proses Pemotongan Bambu

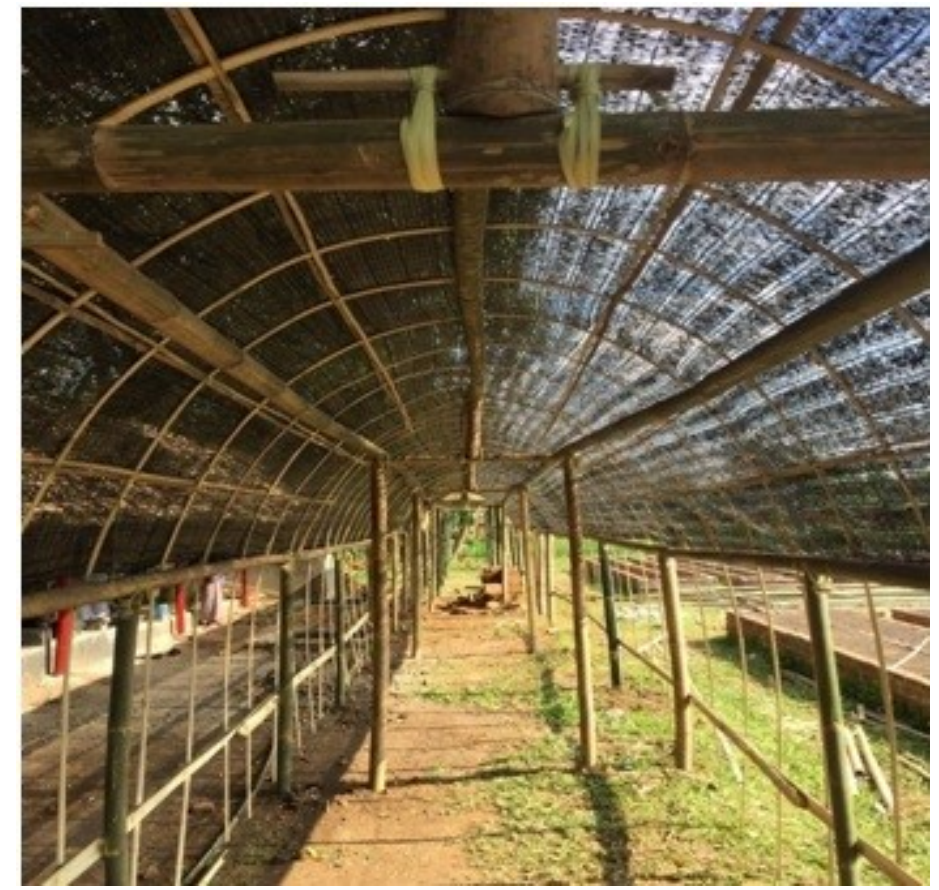

Gambar 3. Setelah bahan bambu terpasang (dari dalam)

- Pada proses ini bambu yang digunakan adalah bambu tutul. Dengan pemilihan bambu yang tepat maka akan lebih mempermudah saat pengerjaan, dan juga 
[77] Muhammad Suayib, dkk / To Maega : Jurnal Pengabdian Masyarakat, Vol. 4; No.1.; Februari, 2021

dari segi ketahanan sama dengan bambu yang lainnya, seperti yang terlihat pada (gambar 1).

- Bambu dipotong sesuai kebutuhan (gambar 2), dan setelahnya dilakukan pemasangan.

- Setelah bambu telah terpasang selanjutnya pada bagian atas atau bagian penutup menggunakan atap yang terbuat dari dedaunan. Gunanya adalah untuk meredam hawa panas yang nantinya tanaman yang didalamnya akan kebal dari segala macam cuaca. (gambar 3 ).

- Panjang tempat bahan bambu tersebut adalah 20 meter (sesuai lebar tempat dan jumlah item yang akan di tanam).

2. Pencampuran media tanam.

Tahapan yang kedua yaitu tahapan pencampuran media tanam yang digunakan sebagai media tempat tumbuhnya tanaman.

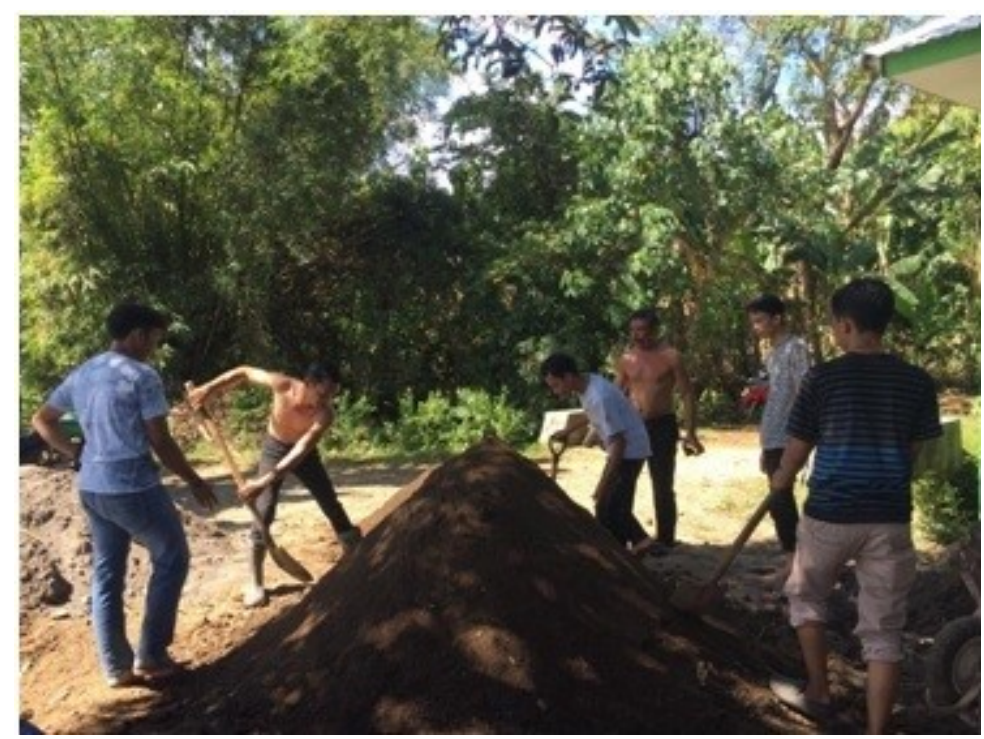

Gambar 4. Proses pencampuran 3 macam media tanam

- Media tanam akan menentukan baik buruknya pertumbuhan tanaman yang pada akhirnya mempengaruhi hasil tanaman. Pada proses ini, terdapat tiga macam bahan yang akan dicampukan, yaitu: Tanah, pasir, dan kulit padi.

- Kemudian, semua bahan media tanam dicampur masing-masing sebanyak 10 gerobak (gambar 4)

- Pencampuran harus benar-benar tercampur secara merata, karena ketiga macam bahan adalah penopang utama dalam kualitas tanaman yang nantinya akan bertahan dan kebal dari setiap macam cuaca 
[78] Muhammad Suayib, dkk / To Maega : Jurnal Pengabdian Masyarakat, Vol. 4; No.1.; Februari, 2021

3. Pengangkatan hasil campuran ke tempat media tanam.

Proses pengangkatan hasil campuran dilakukan secara berkelompok atau tim supaya pengangkatan hasil campuran bisa dipindahkan ke tempat media tanam yang telah disiapkan sebelumnya.

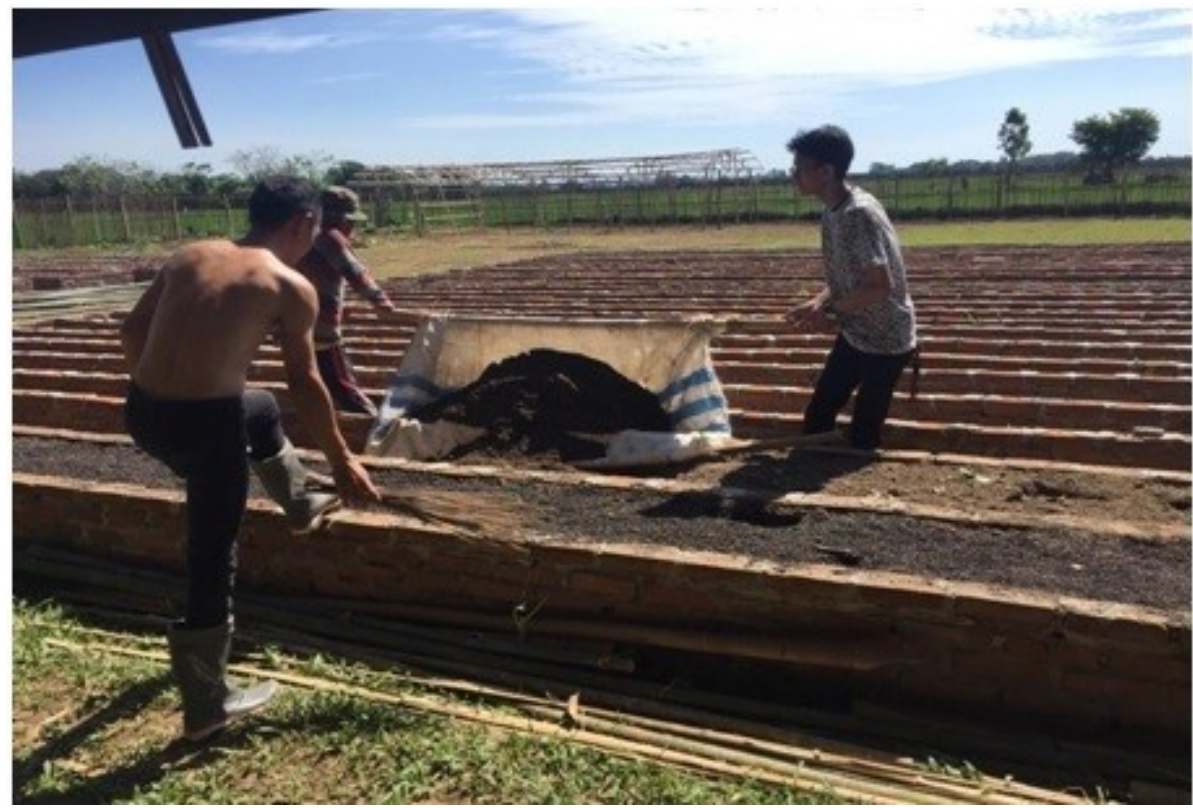

Gambar 5. Pengangkatan Media Tanam Dari Proses Pencampuran Ke Wadah Penanaman

4. Gambaran setelah wadah telah terisi.

Gambaran wadah yang terisi setelah penyimpanan media tanam ditunjukan pada Gambar 6 berikut.

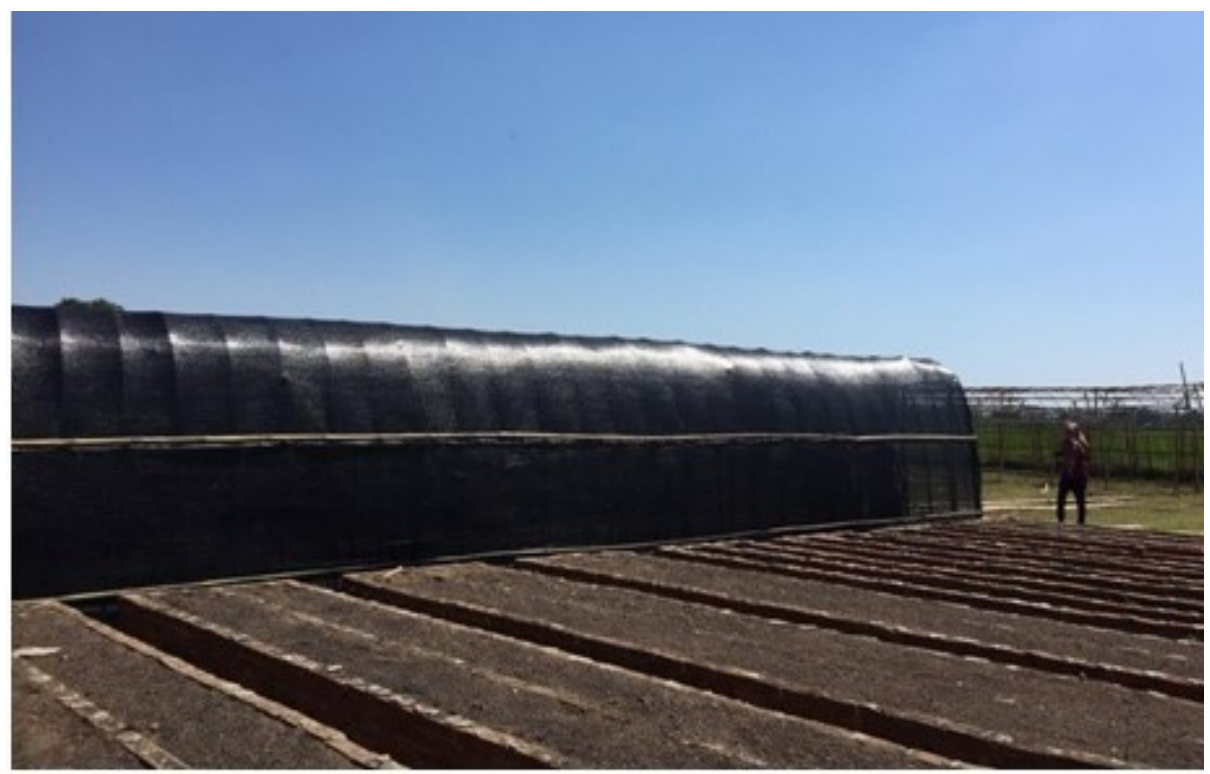

Gambar 6. Setelah Penyimpanan Media Tanam

(C) To Maega / Jurnal Pengabdian Masyarakat. This is an open access article under the CC BY-SA 4.0 license (https://creativecommons.org/licenses/by-sa/4.0/). 
[79] Muhammad Suayib, dkk / To Maega : Jurnal Pengabdian Masyarakat, Vol. 4; No.1.; Februari, 2021

Setelah semua proses pembuatan pola ruang selesai, maka semua item dari jenis item seperti peternakan, perkebunan dan yang lainnya siap untuk di terapkan pada pola ruang ini. Selanjutnya, tinggal tunggu hasil dari budidaya ini, yang nantinya akan di manfaatkan secara luas oleh masyarakat setempat.

\section{Kesimpulan}

Pembuatan pola ruang ini adalah usaha untuk memanfaatkan segala potensi sumber daya alam yang ada, tidak mengacu hanya ke sektor pertanian saja namun dari sector lain seperti perkebunan, peternakan dan perikanan bisa lebih meningkatkan kesejahteraan masyarakat. Hal ini dapat menjadi landasan pengembangan kekuatan ekonomi khususnya daerah pedesaan dengan pemanfaatan sumber daya alam yang ada. Sumber daya alam dalam pola ruang bisa menjadi basis usaha perekonomian dan juga akan menopang semakin bertambahnya kebutuhan dari segala aspek.

\section{Ucapan terima kasih}

Penulis mengucapkan banyak terima kasih kepada semua team yang telah berpartisipasi, Muhammad Nur, Muh. Akram, Ryan Kurniawan, Muh.Hairu Iksan, Agus Yudistira, M. Rizal Rica Fitria, Resky Ayu Ramdhani, Shentha Maya Sari, St. Soraya Budiarti, dan pemerintah setempat yakni pemerintah Kecamatan Pattallassang terkhusus kepada pemerintah Desa Sunggumanai, terutama kami ingin mengucapkan terima kasih kepada kepala Desa Sunggumanai bpk Abdul Rivai, para staf Desa dan tokoh masyarakat yang telah memberikan dukungan moral dan data terhadap program magang daerh kami.

\section{DAFTAR PUSTAKA}

Andini, U. H. (2015). Pemberdayaan ekonomi masyarakat dari desa tertinggal menuju desa tidak tertinggal (Studi di Desa Muktiharjo Kecamatan Margorejo Kabupaten Pati). Jurnal Administrasi Publik, 3(1), 7-11.

Arico, Z., \& Jayanthi, S. (2018). Pengolahan limbah plastik menjadi produk kreatif sebagai peningkatan ekonomi masyarakat pesisir. Martabe: Jurnal Pengabdian Kepada Masyarakat, 1(1), 1-6.

Danial, A., Darusman, Y., Mustakim, M., \& Herwina, W. (2019). Model Pemberdayaan Masyarakat Melalui Pola Magang Tradisional Dalam Upaya Peningkatan Wirausaha Masyarakat. Jurnal Inovasi Hasil Pengabdian Masyarakat (JIPEMAS), 2(1), 31-48. 
[80] Muhammad Suayib, dkk / To Maega : Jurnal Pengabdian Masyarakat, Vol. 4; No.1.; Februari, 2021

Desa sunggumanai (2020). Monografi Desa, Sunggumanai kec Pattallassang Kab.Gowa diakses dari https://id.wikipedia.org/wiki/Sunggumanai,_Pattallassang,_Gowa

Didiharyono, D., Tenrigau, A. M., \& Marsal, M. (2018). Pemanfaatan Sampah Plastik Untuk Dijadikan Bantal Yang Berkualitas Dan Bernilai Ekonomis Di Desa Tolada Kecematan Malangke Kabupaten Luwu Utara. To Maega| Jurnal Pengabdian Masyarakat, 1(1), 8-13.

Didiharyono, D., \& Qur'ani, B. (2019). Increasing Community Knowledge through the Literacy Movement. To Maega: Jurnal Pengabdian Masyarakat, 2(1), 1724.

Indardi, I. (2018). Peningkatan Ekonomi Masyarakat Melalui Pembuatan Keripik Singkong Di Semuluh Kidul, Semanu, Gunung Kidul. BERDIKARI: Jurnal Inovasi dan Penerapan Ipteks, 6(1), 53-64.

Intisari, I., \& Rosnina, R. (2019). Pemberdayaan Masyarakat Melalui Pelatihan Berbagai Olahan Jantung Pisang Di Desa Pabbarasseng Kecamatan Bua Kabupaten Luwu. To Maega| Jurnal Pengabdian Masyarakat, 2(2), 58-62.

Marlinah, L. (2018). Antara Target dan Realisasi Pertumbuhan Ekonomi Indonesia Tahun 2017. JURNAL EKONOMI, 20(1), 82-89.

Sapareng, S., \& Rosnina, R. (2019). Pemberdayaan Masyarakat Melalui Wirausaha Kripik Ikan Teri Di Kampung Nelayan Kota Palopo. To Maega| Jurnal Pengabdian Masyarakat, 2(1), 25-29.

Siwu, H. F. D. (2019). Strategi pertumbuhan dan pembangunan ekonomi daerah. Jurnal Pembangunan Ekonomi Dan Keuangan Daerah, 19(3).

Soerianegara. (1997). Pengolahan Sumber Daya Alam, Bagian I, Sekolah Pasca Sarjana, Ipb Bogor. Diakses dari http://psl.ipb.ac.id/

Suryana, H. (2000). Ekonomi Sumber Daya Manusia. Penerbit Salemba Empat. Jakarta. 